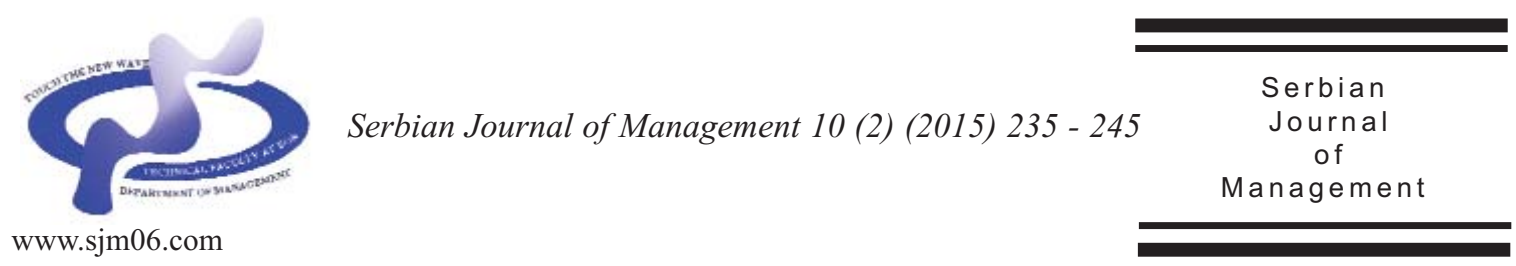

\title{
CREATING COMPETITIVE ORGANIZATIONAL STRATEGY USING THE FUNNEL METHOD
}

\author{
Lidija Stefanovska $a^{a^{*}}$ and Mende Soluncevski ${ }^{b}$ \\ $a_{B A S}$ Institute of management Bitola, str. Dovledzik bb, 7000 Bitola, \\ Republic of Macedonia

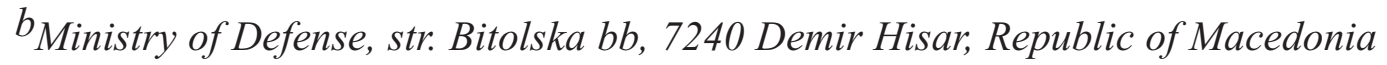

(Received 22 June 2015; accepted 25 September 2015)

\begin{abstract}
In the highly competitive environment of the 21 st century, organizations must be able to effectively change through the application of effective strategies, quickly and in a way that the competitors will be unable to imitate. Therefore, the essential question in any organization is how to achieve and maintain competitive advantage. In this regard, strategic leaders should first logically consider what will bring a substantial advantage to the organization in a long-term, and then start with the process of creating the strategy. To achieve this, researchers in the field of managerial issues offer a concept of continuous process that begins by looking at the customers pattern, through defining the competitive environment and the place of business in it and finally categorizing several strategic business conditions, as a precondition for election and creation of a competitive strategy. This process can be presented as the "funnel for selection of competitive strategy", in whose widest part we can put the customer matrix, in the middle part we can place definitions of the business outlook of the business and the position of the organization in those perspectives. In order to implement the "Funnel method" of strategic planning teams we need accurate, timely and relevant information based on which we can bring appropriate organizational strategy. The subject of this paper is displaying the Funnel method for selection of the competitive strategy, and presentation of the situation in some of the organizations in the Pelagonija region, related to the way and the information used to create organizational strategies through the Funnel method.
\end{abstract}

Keywords: strategy, strategic tools (funnel), competitive advantage

\section{INTRODUCTION}

Strategic management as a complex process, often in the course of its evolution perceived changes in concepts and methods, but today advocates and promotes two important issues that are particularly important in the process of creating the organizational strategy. Namely, the organizational strategy that should provide

\footnotetext{
* Corresponding author: l_stefanovska@yahoo.com

DOI:10.5937/sjm10-8575
} 
the look forward promotes that organizations should not only compete within the existing markets with the existing resources, but should constantly expand within its competitive boundaries.

The second part refers to the method of creating organizational strategies which should not only be an obligation for the top of the organizational pyramid, but its adoption should be a much broader composition of participants in order to enhance the creative and informative input (Littler et al., 2000).

The process of generating a matrix of purchase gives a great contribution in creating organizational strategies. Of particular importance is how the team for strategic planning experiences and perceived the customers and their needs, especially for key products / services. To achieve this, before creating the pattern of purchase it is necessary to provide sufficient information not only for customers, but also for the current competition.

What it is and where does the matrix of customers come from? It is the perception of customers perceived use value (perceived use value-PUV) of products offered by the company for the price charged for them (perceived price-PP).

Based on the pattern of the buyers of the team for strategic planning, two strategic directions are available. Strategic direction west-based on strategies for reducing the cost or strategic direction north based on strategies to enhance the value of the product. However, by combining these two basic strategic directions one can develop a range of strategies that have positive and negative features and hide more or less hidden success risks (Bouman, 2003). According to the research conducted by Bouman, in addition to these two major strategic directions of the organizations, other strategic directions arising from changes in customer requirements and use value of the product are available. For example, increased cost combined with increased use of the product values, discounted price at the expense of reduced use value of the product and so on, and created depending on the requirements of potential clients, based on the capabilities of the organization to implement its strategy

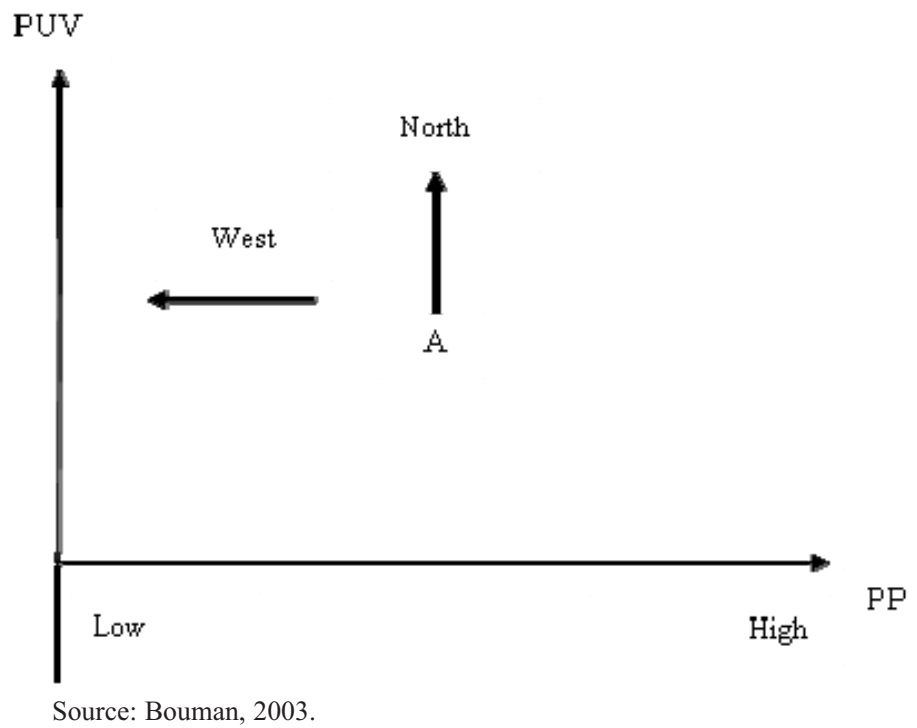

Figure 1. Customer matrix 
(adapted by Bouman, 2003).

The authors Selden and Colvin also promote the principle of putting the customer first. Thus, according to them, organizations need to be proactive and to first identify the customer's needs, and then create ways to meet those needs. Within the research needs of consumers, it is good to perform their segmentation and to discover the needs of each specific group (adapted by Selden and Colvin, 2004) Demanding customers expect innovation, continuous improvement of the products and better understanding of customer requirements, together with enhanced products are becoming the nexus of competition for many organizations (YliRenko and Janakiraman, 2008).

In relation to strategies related to the creation of new products or services, they should primarily be based on a comprehensive analysis of information related to customer needs, or perhaps changed needs of consumers. In terms of collecting information about customer needs, care should be taken of the type of product or service in question, i.e. the involvement of consumers in the purchase of products (Table 1). Namely, whether it is to create strategies that belong to the group of routine purchasing of everyday products, to extensive decision making on very important and expensive products (adapted by Mullins and John, 2012).

\section{APPEAL OF THE ACTIVITY/ STRATEGIC PLANNING PROCESS}

In the process of strategic planning with no less value is the strategic information that the team has available, and refer to the assessment of attractiveness of the activity of the organization and position in the competitive environment. But in this case it is not enough for the strategic team to determine the parameters of the activity, but rather to assess the opportunities and threats that may affect the future development both of the activity and the organization. The timeframe for which the external influences should be predicted varies according to the activity and are left to the organization and planning team to assess the optimal period that can be given a prediction for future developments in the field. Thus, according to the spouses Wall, the prospects in activity may be evaluated as: excellent, good, barely good and bad (Wall and Wall, 1995):

- Excellent - growth is large, usually expressed by double digits;

- Good - growth is above average, usually $2-3 \%$ better;

- Barely good- growth is on par with the average and

- Bad- growth is below average or negative.

According to the McKinsey matrix, the attractiveness of the activity is expressed through: market size, growth rate, cycling, competitive structure, barriers at entry,

Table 1. Involvement of consumers purchasing products

\begin{tabular}{llll}
\hline & Level of involvement & \\
\cline { 3 - 3 } $\begin{array}{l}\text { Level } \\
\text { Analysis }\end{array}$ & Enlarged & $\begin{array}{l}\text { Complete-extensive } \\
\text { (Apartment, car) }\end{array}$ & $\begin{array}{l}\text { Limited not loyal } \\
\text { (Vacation, wardrobe) }\end{array}$ \\
& Routine & $\begin{array}{l}\text { Limited loyal } \\
\text { (Wardrobe, cosmetics) }\end{array}$ & $\begin{array}{l}\text { Inert-routine } \\
\text { (Drinks, food) }\end{array}$ \\
\hline
\end{tabular}

Source: Mullins \& John, 2012. 


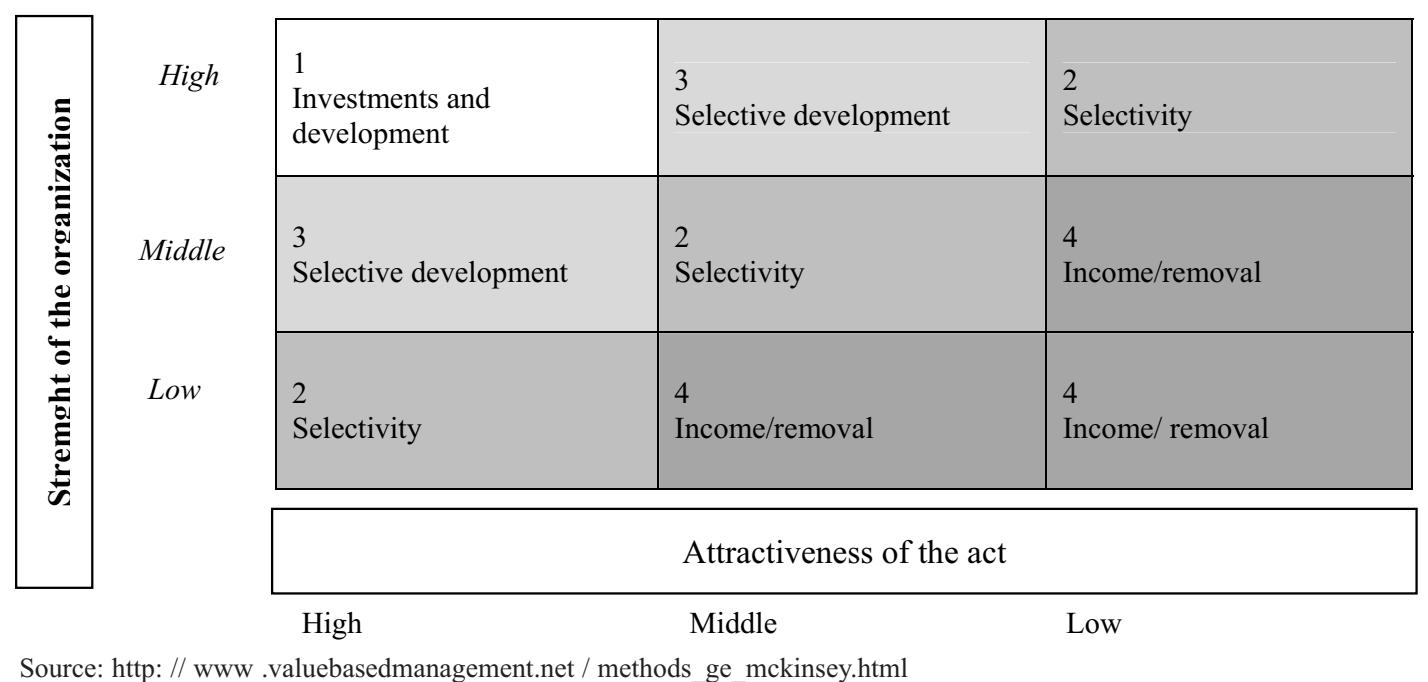

Figure 2. Mc Kinsey matrix of attractiveness of the activity and power of the organization

profitability, technology, inflation, availability of labor, social, environmental, political and legal decisions etc. The meaning of each of these factors is measured separately, and their sum total indicates the attractiveness of the activity that belongs to the organization. The attractiveness of the activity is measured as low, medium, high and is represented on the horizontal axis (Figure 2).

Unlike the analysis of the attractiveness of the activity, which evaluates each factor based on assumptions or predictions for the future, the analysis of the position of competitors focuses on organization and competition now. The strength (power) of the organization is expressed through: market share, marketing, research and development, manufacturing, distribution, financial resources, reputation, breadth of product line, managerial competence etc. The power of the organization is measured as low, medium and high, on the vertical axis.

The matrix varies into four zones. The first zone is characterized by high attractiveness of the industry and a great power of the organization. In this area growth strategies of the organization are created. The second zone covers medium to low attractive activity. The organizations in this area should use selective strategies of stability. The third zone also includes medium attractive business with medium powerful organizations. Organizations of this area may use limited development strategies. The fourth zone covers activities which are medium or low attractive, but their organizations or business units are powerful. From here one needs to use decrease strategies. These strategic situations i.e. the assessment of the organization in which zone is located, is a condition for creating a variety of strategies (Hax and Majluf, 1984).

Based on the evaluation of strategic situations, it is of particular importance for the organization to be the first to achieve market entry. This strategy can result in numerous advantages. Among the most important are: less competition, secure important channels with the most important suppliers and distributors, the best position to meet the needs of the customers, market opportunities, cost advantages, etc. (adapted according to Hisrich et al., 2010). 


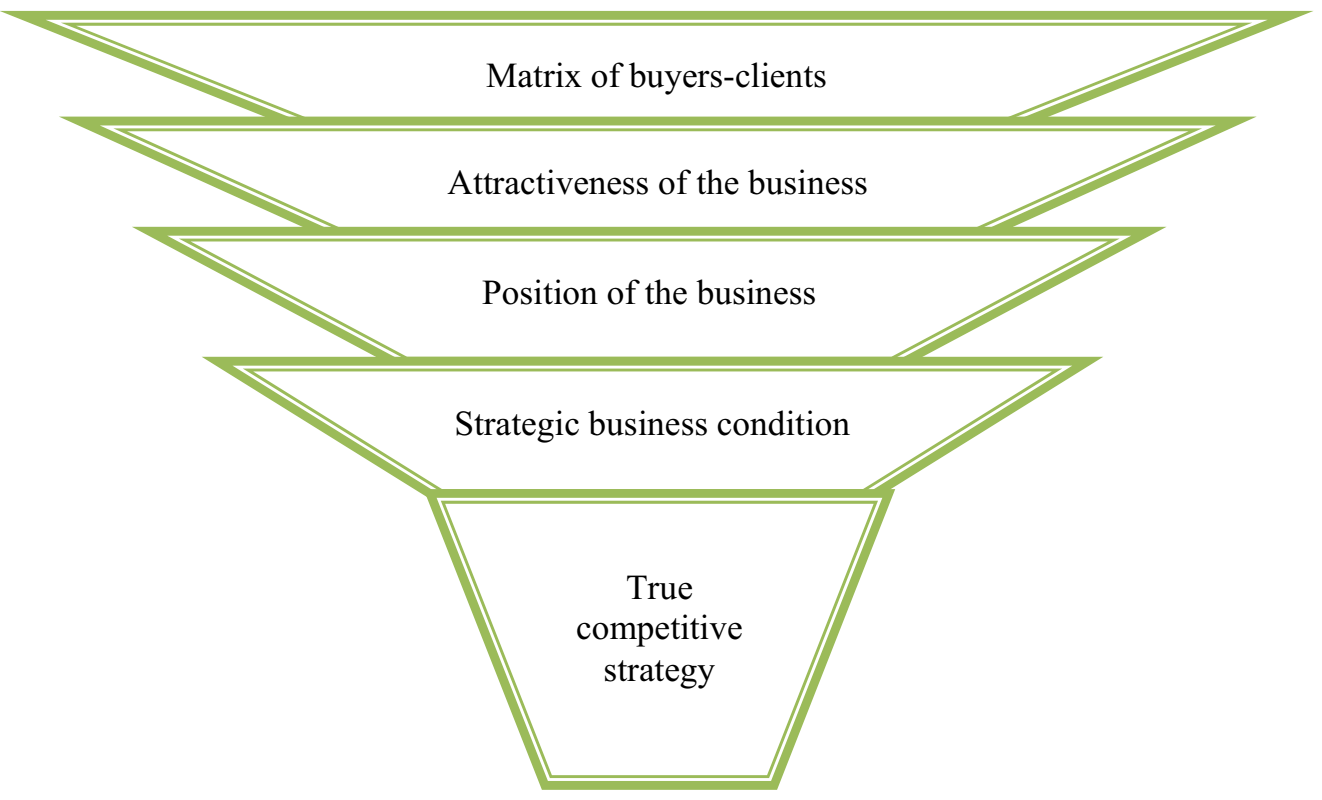

Figure 3. The Funnel method of selection of competitive strategy

It is clear that the organization which enters with its product or service first in the market gains an advantage. However, this advantage should be retained in the long term, and this will only be achieved if the organization creates competitive strategy based on previous methods. It seems two aspects are very important at the entrance of the "funnel" of developing a competitive strategy. These are: at the entrance in the market further effective identification of the target market, and in it designing a proposal for value offer for the target consumers in that target market. (Cherneev, 2010).

In fact, the decision-making processes within modern organizations are often too complex and dynamic to effectively address only through an intuitive approach, and in this context recommended actions of analysis, synthesis and mathematical models which will greatly help in obtaining information from which depends the future of the organization (adapted according to Vercellis, 2009).

\section{RESEARCH SECTION}

The research is conducted within the research program of BAS Institute of Management Bitola "Developing Strategically Focused Organizations on Competitiveness", whose main objective is to determine the factors that affect the competitiveness of companies through the implementation of three sub-projects in the domain of strategic and operational management, innovation and organizational change. The research results in this paper will be presented to organizations that are part of Pelagonija region in the Republic of Macedonia, which are within the MSMEs.

The research goal that is set in this paper is aimed at discovering the ways in which organizations create future strategic plans, how they receive information on market needs and which are included in the creation of the strategic plan. These data are particularly important for the application of the "funnel method" because without sufficient information and involvement of 
employees in the process of strategic planning, a specified method would have its form but not its true essence. The research objective is also in line with the challenges and the problems faced by MSMEs in the process of strategic planning, and is based on information obtained from the field with practical application of strategic management, particularly as a process implemented by MSMEs. The scientific justification of the paper is aimed at generating new scientific knowledge that will find the appropriate application not only among MSMEs, but also for prospective students at study programs in the field of professional management, to foster awareness of the more professional practice of strategic management in MSMEs.

In order to obtain reliable data, during the research questionnaires were being used. In this way, the basic requirements in the research are: objectivity and comparability, by using statistical processing to obtain data in the direction of the scientific objective of the paper. The survey uses the instrument "Analysis of the strategic plan and other strategic documents" and some of the questions from the instrument "Analysis of operational performance" that were completed by the representatives of the top management and operational managers. The answers of the questions in the questionnaire were analyzed, whereby certain frequencies are set and a chi - square test for each question has been made.

\section{RESULTS AND DISCUSSION}

Part of the attention and the data that we wanted to get using the questionnaire was which information from the external environment is the most important to the organizations in the process of strategic planning. In this context several categories have been offered, which the managers ranked according to priority of importance. Here are the results that were reached.

If we analyze the results from the graph in Fig.1, it can be seen that in the preparation of a successful strategic plan, organizations need information. The classification of information by the top management refers to the conclusion that most organizations are interested in and need information on customers, less on competition, and then the information on suppliers and distributors, and the least important information is the one obtained from open sources such as websites, portals, newspapers, etc.

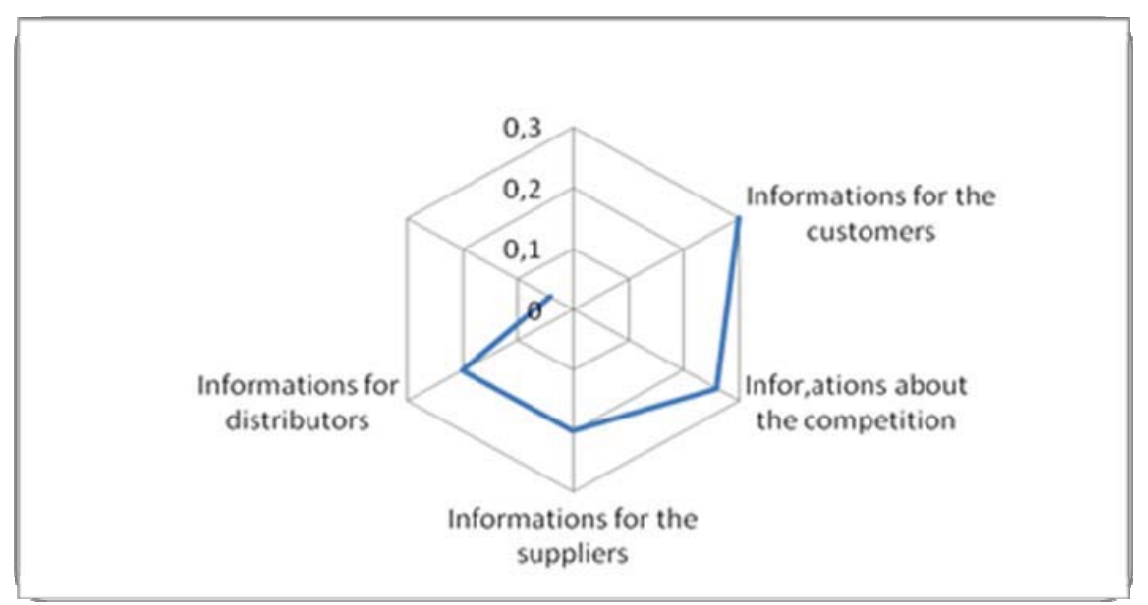

Figure 4. Ranking of the types of information needed in the process of strategic planning 
Table 2. Is there a rulebook for collecting ideas from employees

\begin{tabular}{|c|c|c|c|c|}
\hline Statement & Reply & Rate & \multicolumn{2}{|c|}{ Test Statistics } \\
\hline no & 2 & $11.76 \%$ & & VAR00001 \\
\hline partial & 4 & $23.53 \%$ & Chi-Square & $7.706^{\mathrm{a}}$ \\
\hline significant & 9 & $52.94 \%$ & $\mathrm{df}$ & 3 \\
\hline Full & 2 & $11.76 \%$ & Asymp.Sig. & .052 \\
\hline
\end{tabular}

From the instrument Analysis of the Strategic Plan and other Strategic Documents several questions have been provided for analysis. Namely, one of the questions refers to whether the organization has a rulebook how to gather ideas from employees. In this way we want to obtain an idea for the initial input in the implementation of the Funnel method, when it comes to setting the competitive strategy of the organization.

From the inspection of the table 2 it can be concluded that only a small percentage, i.e. $11.76 \%$ of organizations have a full rulebook for collecting ideas from employees. In more than half of surveyed organizations such rulebooks are significant, yet not a small percentage of organizations have partial rulebook or non-existent. According to the obtained values of chi squared test it can be concluded that there are no statistically significant differences in frequencies between the statements of the respondents, of which we received indicate values $(\mathrm{df}=3, \mathrm{n}=17)$ Chi-Square $=7.706$, and $\mathrm{p}=0.052$ (Sig. $=.052)$.

In order to see whether there is documentation for the development of new products and services, the answers given by top managers of surveyed organizations to the questionnaire "Analysis of organizational performance" will be analyzed.

Namely, for the question: "Is there documentation for development of new products and services" a four-level scale is offered to which the operating managers responded when completing the questionnaire. The results are shown in the table 3.

From inspecting the table 3 , it can be seen that in more than half of the surveyed organizations there is complete documentation ran by organizations and is related to the development of a new product or service. And according to the obtained values of chi - square test it can be concluded

Table 3. Is there documentation for development of new products - Chi-Square

\begin{tabular}{|c|c|c|c|c|}
\hline Statement & Reply & Rate & \multicolumn{2}{|c|}{ Test Statistics } \\
\hline İo & 0 & 0 & & VAR00001 \\
\hline Partial & 1 & $5.88 \%$ & Chi-Square & $8.941^{\mathrm{a}}$ \\
\hline Significant & 5 & $29.41 \%$ & df & 2 \\
\hline Full & 11 & $64.71 \%$ & Asymp.Sig. & .011 \\
\hline
\end{tabular}

Table 4. If the strategic plan is intended to improve the products/services - Chi-Square

\begin{tabular}{|c|c|c|c|c|}
\hline Statement & Reply & Rate & \multicolumn{2}{|c|}{ Test Statistics } \\
\hline no & 0 & $0 \%$ & & AR00001 \\
\hline partially & 0 & $0 \%$ & Chi-Square & $529^{\mathrm{a}}$ \\
\hline Substantially & 7 & $41.18 \%$ & $\mathrm{df}$ & 1 \\
\hline Fully & 10 & $58.82 \%$ & Asymp.Sig & .467 \\
\hline
\end{tabular}


that there are statistically significant differences in frequencies between the statements of the respondents, of which we received indicate values $(\mathrm{df}=2, \mathrm{n}=17)$, Chi -squere $=8.941$ and $p=0.011$.

Regarding the question whether the strategic plan is intended to improve the products / services, the results are given in the table 4. It can be concluded that more than half of the surveyed organizations, i.e. $58.82 \%$ of them in the strategic plan intended to improve the products / services and in nearly approximate percentage of surveyed organizations there is a significant prediction to improve products / services. And according to the obtained values of chi square test it can be concluded that there are no statistically significant differences in frequencies between the statements of the respondents, of which we received indicate values $(\mathrm{df}=1, \mathrm{n}=17)$, Chi-squere $=0.529$ and $\mathrm{p}=0.467$.

In terms of the fact that major sources of innovation in the organization are the employees, it is necessary to enable them to present their ideas. For this purpose the next issue that was analyzed was whether innovation can be seen in the defined organizational goals. The results are presented in the table 5 .

If we analyze the answers in the table 5 , it can be concluded that in all of the organizations surveyed, innovations can be seen in the set organizational goals significantly or completely. It is satisfactory to see that the statements move within significantly and completely and there is no organization which does not apply the proposition. According to the obtained values of the chi - square test, it can be concluded that there are no statistically significant differences in frequencies between the statements of the respondents, suggested by the values obtained $(\mathrm{df}=1, \mathrm{n}=$ 17), Chi-square $=0,059$ and $p=0.808$.

Regarding the question "Does the adoption of the strategic plan involve a larger number of employees," the results are processed and percentages shown in the table 6.

From the inspection of the table 6, it can be concluded that in more than half of the surveyed organizations, employees significantly participate in the creation of the strategic plan, in a small percentage fully participate, and the same percentage were partly involved in the process of creating a strategic plan.

Table 5. In organizational goals can be seen innovation - Chi-Square

\begin{tabular}{|c|c|c|c|c|}
\hline Statement & Reply & Rate & \multicolumn{2}{|c|}{ Test Statistics } \\
\hline no & 0 & $0 \%$ & & VAR00001 \\
\hline partially & 0 & $0 \%$ & Chi-Square & $.059^{\mathrm{a}}$ \\
\hline Significantly & 9 & $52.94 \%$ & df & 1 \\
\hline Fully & 8 & $47.06 \%$ & Asymp.Sig. & .808 \\
\hline
\end{tabular}

Table 6. Employee participation in creating SP - Chi-Square

\begin{tabular}{|c|c|c|c|c|}
\hline Statement & Reply & Rate & \multicolumn{2}{|c|}{ Test Statistics } \\
\hline no & 0 & $0 \%$ & & VAR00001 \\
\hline partially & 4 & $23.53 \%$ & Chi-Square & $2.941^{\mathrm{a}}$ \\
\hline Significantly & 9 & $52.94 \%$ & df & 2 \\
\hline Fully & 4 & $23.53 \%$ & Asymp.Sig & 230 \\
\hline
\end{tabular}


According to the obtained values of chi square test, it can be concluded that there are no statistically significant differences in frequencies between the statements of the respondents, of which we received indicate values $(\mathrm{df}=2, \mathrm{n}=17)$, Chi-square $=2.941$ and $\mathrm{p}=0.230$.

\section{CONCLUSION}

Today, in conditions of intense change of external environment characterized by numerous, complex and dynamic factors, the key to success and long-term survival in the activity and preserving the leading position in the market is possible only through the implementation of effective strategies, quickly and in a way that to competitors would be difficult to imitate.

Besides involving of all employees in the company in an appropriate manner, the creation of an effective strategy requires logical sequence of strategic thinking, analysis and selection strategy. Today strategic leaders have available a number of strategic mechanisms which for different activities and different businesses are more and less effective in the appropriate situation. It is very important to select the right ones timely and in sequence. The Funnel method offers such a logical sequence of methods, procedures and tools in the process of creating and selecting the right strategy of the company. However, particular importance for making the right strategic decisions and essential application of the Funnel method requires reliable and timely information as to the requirements of customers and the market place and the organization of that market.

On the other hand, it is important to utilize the potential that the employees have in the organization, as well as create a culture where ideas can freely be expressed, based on which in the future may come to the improvement of existing products / services or create new ones in order to meet the customer needs. This practice can be confirmed in a sense that almost all surveyed organizations are trying innovate in their strategic goals. No less important is the participation of employees in the creation of the strategy in terms of making good decisions for determining the future direction of development of the organization. In this context, it has proved that many of the surveyed organizations significantly activate employees in creating strategic plans.

\section{References}

Bouman K., (2003), Strategy in practice, Prometej, Novi Sad, pp, 20-36;

Chernev, A., Strategic Marketing Management, Brighstar media (translation) Strategic Marketing Management, Ars Lamina, Skopje, 2010, pp.24;

Hax, A., and Majluf, N. (1984) Strategic Management, An integrative perspective, Prentince Hall, pp.156;

Hisrich, R., Peters, M., and Shepherd, D., (2010) Enterpreneurship, (translation) Pretpiemashtvo, Ars Lamina Skopje., pp.74;

Littler K. , Aisthorpe P., R. Hudson, K. Keasey, A new Approach to linking strategy Formulation and strategy Implementation: an Example from the UK banking Sector International Journal of Information Management 20 (2000) pp. 411-428;

Mullins J., John W, Marketing management approach to strategic decisionmaking, Ars Lamina, Skopje 2012, pp.101;

Selden L., and Colvin A., (2004), 5 Rules for Finding the Next Dell, Fortune;

Vercellis C., (2009), Business 


\title{
ПЛАНИРАЊЕ И СТВАРАЊЕ КОНКУРЕНТНЕ ОГАНИЗАЦИОНЕ СТРАТЕГИЈЕ ПРИМЕНОМ МЕТОДЕ ЛЕВКА
}

\author{
Лидија Стефановска и Менде Солунчевски
}

\section{Извод}

У високо конкурентном окружењу дваесет првог века, потребно је да организације буду способне за ефикасно адаптирање применом ефективних стратегија. Ради бољег ефекта, неопходно је да се организационе промене одвијати брзо и на начин који ће онемогућати скору адаптацију, а самим тим и угрожавање од стране конкурената. Због тога, начин постизања и одржавања конкурентске предности, суштинско је питање било које организације. У том смеру, лидерски менаџмент најпре треба да усвоји логику о начинима стицања суштинске предности организације на што дужи временски период, а затим да отпочне са процесом креирања стратегије. Да би се то постигло, они који се баве проблемима менаџмента нуде концепт континуираног процеса, који отпочиње разматрањем матрице купаца, дефинисањем конкурентског окружења и заузимањем што боље пословне позиције унутар њега. На крају, нуди се категоризација више стратегијских пословних могућности, као услов за избор и стварање конкурентне стратегије.

Овај процес се претставља као “левак за избор конкурентских стратегија”, при чему се у његов најшири део може поставити матрица купаца, која омогућава стратегијско и логичко размишљање о потребама клијената. У средишњем делу се налазе пословне дефиниције, перспективе и позиција организације у тим перспективама. Свакако, како би "метода левка" била спроведена, тимовима за стратегијско планирање су потребне тачне, благовремене и релевантне информације, на основу којих се може донети и адекватна стратегија.

Предмет овог рада је представљање примене “метода левка" при избору конкурентске стратегије. Уједно, циљ је приказивање неколико организација у Пелагонијском региону, тј. њиховог начина прикупљања и примене информација у процесу планирања и стварања организационе стратегије применом "методе левка".

Кључне речи: организациона стратегија, стратегијски метод (левак), конкурентска предност

Intelligence, Business Intelligence: Data Mining and Optimization for Decision Making, Politecnico di Milano, Italy. , John Wiley and Sons, Ltd., Publication, pp. 19-20;

Yli - Renko, H., and Janakiraman, R., (2008), How customer portfolio affects new product development in technology - based entrepreneurial firms, Journal of marketing, 72 (5): 131-148; from Jalali SH, Environmental determinants, entrepreneurial orientation and export performance; empirical evidence from Iran, Serbian Journal of management, volume 7, number (2) 2012, pp. 248;

Wall S. J., and Wall S. R., (1995), The New Strategists, Free Press, New York, pp. 201-210;

\section{Web references}

http://www.valuebasedmanagement.net/ methods_ge_mckinsey.html 


\section{Appendix: Analysis of the Strategic Plan and other strategic documents}

Explanation: This scale of assessment is part of the research by the staff in BAS Institute of Management Bitola, who, in cooperation with your company, explores the competitiveness of the companies in the Republic of Macedonia through the Macro project "Developing Strategically Focused Organization for Competitiveness". The primary objective of this project is to obtain applicable knowledge, which will make the working environment more satisfactory and more productive, and thus increase the competitiveness of your organization.

The results obtained by the analysis of this instrument will be used solely for research purposes. The results for your company, compared with the results of other companies, will be presented in a summary by category and will assist your management, along with us, to design organizational interventions that will improve your work and the competitiveness of your organization.

\section{Completion instructions:}

Please carefully read each question. Next to each statement, circle the number that you think best suits the current situation using the following scoring system: $1=$ insufficient; $2=$ partially 3 = significantly, $4=$ completely.

\section{Concept and creation of the Strategic Plan (SP)}

\begin{tabular}{lllll}
\hline \multicolumn{1}{c}{ Proposition } & \multicolumn{3}{c}{ ASSESSMENT } \\
\cline { 2 - 5 } & No & Partially & Significantly & Fully \\
\hline $\begin{array}{l}\text { 1. There is a rulebook where it is prescribed how to } \\
\text { collect ideas from employees }\end{array}$ & 1 & 2 & 3 & 4 \\
$\begin{array}{l}\text { 2. The SP envisages improvement of products / } \\
\text { services }\end{array}$ & 1 & 2 & 3 & 4 \\
$\begin{array}{l}\text { 3. Within the defined organizational goals one can } \\
\text { see innovation }\end{array}$ & 1 & 2 & 3 & 4 \\
$\begin{array}{l}\text { 4. In making the SP a larger number of employees } \\
\text { participated }\end{array}$ & 1 & 2 & 3 & 4 \\
$\begin{array}{l}\text { 5. Documentation for development of new } \\
\text { products exists }\end{array}$ & 1 & 2 & 3 & 4 \\
\hline
\end{tabular}

